Jolanta Jakóbczyk-Gryszkiewicz

https://orcid.org/0000-0001-6250-6873

Uniwersytet Łódzki

Wydział Nauk Geograficznych

Instytut Geografii Miast, Turyzmu i Geoinformacji

jolanta.gryszkiewicz@geo.uni.lodz.pl

\title{
IMIGRANCI W POLSKICH MIASTACH PRZYKŁAD PABIANIC W REGIONIE ŁÓDZKIM
}

\begin{abstract}
Abstrakt: Celem pracy jest prezentacja ruchów imigracyjnych w Pabianicach, które są jednym z miast regionu łódzkiego. W związku z rozwojem przemysłu cudzoziemcy przybywali tam od początków XIX w. Dzięki nim miasto rozwinęło się jako znaczący ośrodek przemysłu włókienniczego, a oni sami oraz ich potomkowie stali się jego obywatelami. Drugim okresem intensywnego napływu cudzoziemców był początek XXI w., zwłaszcza czas po wstąpieniu Polski do Unii Europejskiej (UE). W poszukiwaniu pracy do Pabianic przybyli najliczniej cudzoziemcy spoza UE, głównie z Ukrainy i z Indii. Hindusi pracują we własnych hurtowniach tkanin oraz osiedlają się na dłużej, zaś Ukraińcy i inne nacje znajdują zatrudnienie w handlu, gastronomii, przemyśle i na budowach w systemie rotacyjnym - pracują w Polsce, wracają do własnego kraju i ponownie przyjeżdżają do Polski. Mieszkańcy Pabianic dostrzegają zarówno spuściznę cudzoziemców dziewiętnastowiecznych, jak i działalność obecnych imigrantów. Ich stosunek do cudzoziemców jest na ogół pozytywny.
\end{abstract}

Słowa kluczowe: imigracja, imigranci, cudzoziemcy, mniejszości narodowe, mniejszości etniczne, spuścizna, kierunki imigracji, Pabianice, region łódzki.

\section{IMMIGRANTS IN POLISH CITIES: THE CASE OF PABIANICE IN THE ŁÓDŹ REGION}

Abstract: The aim of this work is to present immigration processes in Pabianice, one of the towns in the Łódź region. Foreigners, mostly Germans, were arriving here from the beginning of the $19^{\text {th }}$ century in connection with industrial development. They contributed to the growth of this city when it was becoming a major centre of the textile industry and later they and their descendants became its citizens. The second period of intensive immigration is the beginning of the $21^{\text {st }}$ century after Poland's accession to the EU. The majority of present-day immigrants are arriving from outside the EU, mainly from Ukraine and India. Those from India, who settle for a longer time, work in their wholesale clothing outlets, while Ukrainians and representatives of other nations find work in trade, catering, manufacturing and construction on a temporary basis - returning home and coming back again. Today, the residents of Pabianice appreciate the effects of the activity of both $19^{\text {th }}$ century and present-day immigrants. Generally, their attitude to foreigners has been positive.

Keywords: immigration, immigrants, foreigners, national minorities, ethnic minorities, heritage, immigration directions, Pabianice, Łódź region.

\section{WPROWADZENIE}

Celem pracy jest przedstawienie procesów imigracji na ziemiach polskich, począwszy od XIX w., ze szczególnym uwzględnieniem XXI w., na przykładzie Pabianic - miasta wchodzącego w skład aglomeracji łódzkiej. Ze względu na intensywny rozwój przemysłu w XIX w. miasta polskie zaludniali imigranci z lepiej rozwiniętych gospodarczo krajów europejskich. Wykształcenie i umiejętności techniczne cudzoziemców umożliwiały rozwój gospodarczy. Zagraniczni specjaliści sprowadzani byli często celowo, osiedlali się na stałe i z czasem stawali się obywatelami miasta $\mathrm{w}$ grupie mniejszości narodowych. Pozostawili po sobie bogatą spuściznę. Pabianice dobrze odzwierciedlają procesy migracyjne, przebiegające zarówno w miastach regionu łódzkiego, jak i całego Królestwa Polskiego.

Współcześnie również jesteśmy świadkami intensywnej imigracji do Polski. Zmieniły się jednak jej kierunki i charakter. Najliczniejsze grupy imigrantów pochodzą spoza UE - głównie z Ukrainy, ale coraz częściej też, np. z Dalekiego Wschodu. Imigranci szukają na ogół prac sezonowych, zwykle na gorzej płatnych stanowiskach. Ponadto przyjeżdżają najczęściej na krótko, 
często kilkakrotnie w systemie rotacyjnym, bez zamiaru osiedlania się na stałe. Nawet jeśli mają wyższe wykształcenie, rzadko znajdują odpowiadającą mu pracę.

Problematyką imigracji i imigrantów przebywających i pracujacych w różnych okresach historycznych w Polsce zajmowało się wielu autorów, jak np.: Barwiński (2016), Górny, Grabowska-Lusińska, Lesińska, Okólski (2010), Jakóbczyk-Gryszkiewicz (2018), Konieczna-Sałamatin (2015), Lesińska, Okólski (2013). W niektórych pracach omawiano problem migracji w ujęciu regionalnym, np. Jakóbczyk-Gryszkiewicz (2016), Marszał (2020), Pędziwiatr (2015). Wiele publikacji poświęcono najliczniejszej grupie imigrantów w Polsce, a więc Ukraińcom, np. Brunarska i in. (2012), Chmielewska, Dobraczek, Purynkiewicz (2016), Górny, Kołodziejczyk, Madej, Kaczmarczyk (2019), Kloc-Nowak (2007), Klimek (2015), Lubicz-Miszewski (2018), Paszkowicz, Hrynenko (2019).

Spośród publikacji poświęconych Pabianicom warto przywołać te, które opisują bogatą historię miasta, zwłaszcza w okresie jego szczególnie intensywnego wzrostu w XIX i na początku XX w. (Adamek, Nowak, 2005; Baruch, 1903; Missalowa, 1968; Puś, 1992; Warneńska, 1963). Nie można zapomnieć o pracach poruszających problematykę współczesnych migracji do miasta. O Pabianicach w kontekście mniejszości narodowych i etnicznych pisali: Gmaj (2015), Klimek (2012), Kowarska (2005), Kruś (2016), Patzer (2015), Rykała (2013), Szyszlak (2011).

Materiały źródłowe pozyskano z publikacji Urzędu ds. Cudzoziemców, ze strony internetowej migracje.gov.pl, z Biuletynów Migracyjnych, raportów PwC ${ }^{1}$ czy Personnel Service².

Szczegółowych danych na temat współczesnych Pabianic dostarczyły badania ankietowe, przeprowadzone w 2018 r. i 2019 r. z ich 250 polskimi mieszkańcami oraz z 70 pracującymi i mieszkającymi w mieście cudzoziemcami (Krzykowski, 2019).

\section{POLSKA JAKO KRAJ DOCELOWY IMIGRANTÓW W XXI W.}

W XXI w. w Polsce nasiliły się ruchy migracyjne, dotyczy to zarówno emigracji, jak i imigracji. Po wejściu Polski do UE w 2004 r. młodzi Polacy zaczęli szukać pracy na terenie Unii. W pierwszej kolejności wyjeżdżali do Wielkiej Brytanii i Irlandii, ponieważ te kraje już w pierwszym roku otworzyły swoje rynki pracy przed Polakami, a ponadto decyzję ułatwiała powszechna w młodym pokoleniu znajomość języka angielskiego. Brytyjski urząd statystyczny ONS opublikował w 2018 r. szacunkowe dane, z których wynika, że pod koniec 2017 r. w Wielkiej Brytanii mieszkała rekordowa liczba Polaków - 1,021 mln osób - stanowiąc najliczniejszą mniejszość narodową w tym kraju. W związku z brexitem sytuacja części z nich jest stopniowo regulowana, ale kolejni imigranci, którzy będą chcieli pracować na Wyspach, spotkają się z utrudnieniami i ograniczeniami (ONS, 2020).

Do Polski zaczęli napływać imigranci - przede wszystkim spoza UE. Od lat najliczniejszą grupę cudzoziemców stanowili nasi sąsiedzi zza wschodniej granicy, w tym głównie z Ukrainy (Jakóbczyk-Gryszkiewicz, 2018). Byli to imigranci zarobkowi, którzy w znacznej mierze uzupełnili braki kadrowe na polskim rynku pracy, spowodowane emigracją Polaków.

Imigracja z Ukrainy cały czas się nasilała. W 2010 r. w Polsce wydano zaledwie 180 tys. oświadczeń o zamiarze powierzenia pracy Ukraińcom. W 2017 r. takich oświadczeń było już ponad 1,7 mln - nastąpił wzrost o prawie $800 \%$. W 2017 r. w Polsce pracowało nawet milion obywateli Ukrainy (Personnel Service, 2018).

W 2017 r. został wprowadzony ruch bezwizowy pomiędzy państwami obszaru Schengen a Ukrainą. Od tego czasu obywatele Ukrainy mogą podróżować do krajów UE (z wyjątkiem Wielkiej Brytanii i Irlandii) oraz do Islandii, Liechtensteinu, Norwegii i Szwajcarii bez konieczności posiadania wizy. Ruch bezwizowy ma swoje ograniczenia: Ukraińcy muszą przestrzegać zasady 90 dni (pobyt w strefie Schengen nie dłużej niż 90 dni w ciągu 180 dni), a także nie mogą pracować bez wizy. Tylko w Polsce obywatele Ukrainy mają prawo do pracy bez wizy w przypadku posiadania paszportu biometrycznego. Konieczne jest posiadanie dokumentu uprawniającego do legalnej pracy.

Gdyby nie napływ pracowników z Ukrainy, w 2018 r. w Polsce byłoby nawet milion nieobsadzonych stanowisk pracy, a ponad 5 miliardów złotych nie wchodziłoby do obrotu detalicznego. Mniejszy byłby wzrost PKB, który również jest stymulowany przez Ukraińców.

W raporcie PwC (2019), pt. Rosnaca luka na rynku pracy w Polsce. Jak ja zniwelować?, stwierdzono, że jeśli wzrost gospodarczy w Polsce utrzyma się w tempie zgodnym z prognozami, w perspektywie kilku lat na rynku pracy zabraknie 1,5 mln osób. Około 300-400 tys. osób co roku opuszcza polski rynek pracy. Tworzy się luka generacyjna i w związku z tym pracodawcom będzie brakowało 200-300 tys. pracowników rocznie.

Z raportu Personnel Service (2018), pt. Barometr Imigracji Zarobkowej w I pótroczu 2018 r., wynika, że tylko $11 \%$ Ukraińców chciało się osiedlić w Polsce na stałe. Dla zdecydowanej większości emigracja miała charakter zarobkowy, powtarzalny i krótkotrwały. Na ogół pracują oni w Polsce, po czym wracają z zarobionymi pieniędzmi na Ukrainę, a po jakimś czasie przyjeżdżają ponownie. W 2020 r. pandemia spowodowała znaczne ograniczenia tej aktywności.

Według danych Urzędu ds. Cudzoziemców z 2019 r. cudzoziemcy przebywający w Polsce pochodzili przede wszystkim z: Ukrainy (49,5\%), Białorusi (5,7\%), Niemiec 


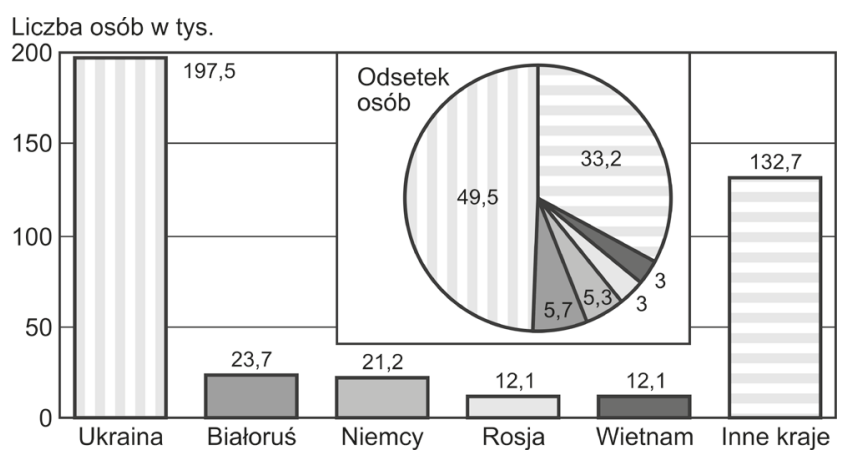

Rysunek 1. Pochodzenie cudzoziemców pracujących w Polsce wg krajów w 2019 r.

Źródło: Urząd ds. Cudzoziemców (2020)

(5,3\%), Rosji (3\%) i Wietnamu (3\%). Te pięć krajów dostarczało prawie 67\% ogółu imigrantów do Polski. Mniej licznie migrowali do Polski Rosjanie i Wietnamczycy (rys. 1).

Około 58\% cudzoziemców posiadających ważne zezwolenia na pobyt $w$ Polsce, to osoby poniżej 35 roku życia. Nieco ponad $38 \%$ stanowią osoby w przedziale wiekowym od 35 do 59 lat, a jedynie $4 \%$ to osoby po 60 roku życia. Powyżej 93\% cudzoziemców w Polsce funkcjonowało $\mathrm{w}$ ramach pobytu czasowego, a jedynie $6,8 \%$ miało pobyt stały. Imigranci z UE rejestrowani jako rezydenci długoterminowi stanowili 1\% (Urząd ds. Cudzoziemców, 2020).

Obcokrajowcy najchętniej osiedlają się w regionach z dużymi ośrodkami miejskimi, oferującymi możliwości pracy i nauki. Najbardziej popularne są województwa: mazowieckie, małopolskie, dolnośląskie, wielkopolskie, śląskie, zachodniopomorskie oraz łódzkie (rys. 2).

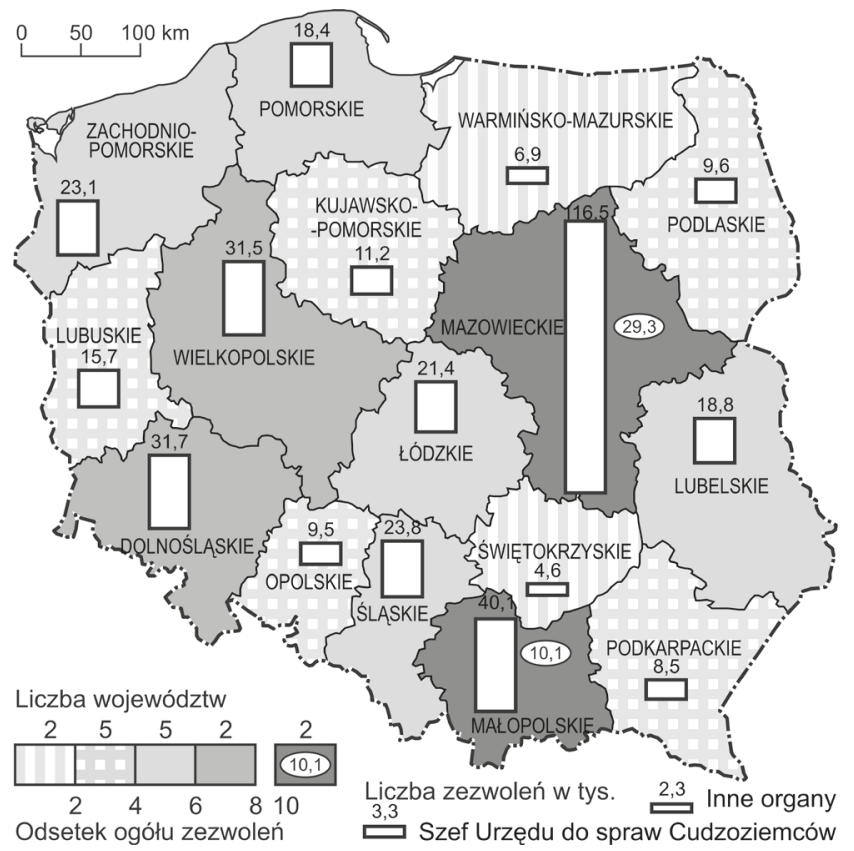

Rysunek 2. Wydane zezwolenia na pobyt cudzoziemców w Polsce wg województw w 2019 r. Źródło: Urząd ds. Cudzoziemców (2020)
Zezwolenia na pracę w ponad $99 \%$ wydawane są przez wojewodów, a w sporadycznych wypadkach przez Szefa Urzędu ds. Cudzoziemców lub inne organy $(0,13 \%)$. Prawie $30 \%$ ogółu pozwoleń pochodzi z województwa mazowieckiego, a ponad $10 \% \mathrm{z}$ województwa małopolskiego (tab. 1).

Tabela 1. Zezwolenia na prace wydawane przez wojewodów w 2019 r.

\begin{tabular}{|l|c|c|}
\hline \multicolumn{1}{|c|}{ Organ } & $\begin{array}{c}\text { Liczba } \\
\text { zezwoleń }\end{array}$ & Udział \% \\
\hline Wojewoda mazowiecki & 116454 & 29,3 \\
\hline Wojewoda małopolski & 40114 & 10,1 \\
\hline Wojewoda dolnośląski & 31714 & 7,9 \\
\hline Wojewoda wielkopolski & 31514 & 7,9 \\
\hline Wojewoda śląski & 23784 & 5,9 \\
\hline Wojewoda zachodniopomorski & 23118 & 5,8 \\
\hline Wojewoda łódzki & 21353 & 5,3 \\
\hline Wojewoda lubelski & 18783 & 4,7 \\
\hline Wojewoda pomorski & 18433 & 4,6 \\
\hline Wojewoda lubuski & 15743 & 3,9 \\
\hline Wojewoda kujawsko-pomorski & 11205 & 2,8 \\
\hline Wojewoda podlaski & 9580 & 2,4 \\
\hline Wojewoda opolski & 9504 & 2,4 \\
\hline Wojewoda podkarpacki & 8524 & 2,1 \\
\hline Wojewoda warmińsko-mazurski & 6889 & 1,7 \\
\hline Wojewoda świętokrzyski & 4620 & 1,1 \\
\hline Ogółem & 396908 & 100,0 \\
\hline
\end{tabular}

Źródło: Urząd ds. Cudzoziemców (2020).

Według raportów Personnel Service (2018) Ukraińcy są zatrudniani w co dziesiątej polskiej firmie $(11 \%)$. Im większe przedsiębiorstwo, tym większy udział pracowników z Ukrainy. Zatrudnia ich 39\% dużych firm, $21 \%$ średnich i zaledwie $6 \%$ małych. Najwięcej Ukraińców pracuje w produkcji (18\%) oraz usługach (15\%). Poszukiwanie kadry ze wschodu w przyszłości deklaruje co siódma firma (14\%). Najwięcej takich deklaracji składają duże zakłady pracy.

Ważnym problemem dotyczącym obcokrajowców w Polsce jest to, iż nawet wybitnych specjalistów w swoich dziedzinach zatrudnia się na słabiej opłacanych stanowiskach, na których nie wykorzystują oni swoich umiejętności. Tak dzieje się na przykład z lekarzami z Ukrainy, jednak wobec trudnej sytuacji na rynku pracy w służbie zdrowia (wywołanej przez epidemię) dostęp do zawodu lekarskiego, jak deklarują władze, będzie ułatwiony.

Emigracja zarobkowa osób z Ukrainy do Polski ma głównie charakter ekonomiczny. Płaca minimalna $\mathrm{w}$ Polsce to $\mathrm{w}$ przeliczeniu 465 euro na miesiąc, a na Ukrainie zaledwie 100 euro przy średniej pensji rzędu 
230 euro. Imigranci chcą w krótkim czasie, zarobić jak najwięcej, żeby móc utrzymać swoją rodzinę, która zostaje na Ukrainie. Ukraińcy wydają bardzo niewielkie kwoty w naszym kraju, aż 66\% z nich żyje za mniej niż 500 zł miesięcznie. Taki model życia nazywany jest modelem przetrwaniowym. Niskie zarobki Ukraińców są przeszkodą w ich osiedlaniu się w Polsce (Personel Service, 2018).

Wybór Polski nie jest przypadkowy. Jak twierdzi V. Voskoboynik (prezes Ukraińskiego Stowarzyszenia Międzynarodowego Zatrudnienia), Ukraińcy łatwo integrują się z Polakami, są postrzegani jako odpowiedzialni i rzetelni pracownicy, co ułatwia im znalezienie pracy, nie mają też problemów z językiem polskim, którego szybko się uczą. Pytani z jakich powodów wybrali Polskę na miejsce emigracji zarobkowej, wskazują na bliskość geograficzną (53,3\%), wysokość zarobków (44\%), niską barierę językową (33\%), obecność rodziny lub znajomych, którzy już pracują w Polsce (Personnel Service, 2018).

Kolejną liczną grupę pracowników z zagranicy tworzą Białorusini. W 2017 r. liczba oświadczeń o zamiarze powierzenia pracy obywatelom Białorusi wzrosła dwuipółkrotnie w porównaniu z 2016 r. - z 23 tys. do 58 tys. Ze względu na trudną sytuację polityczną na Białorusi po wyborach prezydenckich w 2020 r. liczba ta ciągle rośnie.

Według danych Eurostatu w 2019 r. w Polsce wydano w sumie 328 tys. pozwoleń na pobyt w celu podjęcia pracy. To $37 \%$ wszystkich pozwoleń wydanych $\mathrm{z}$ tego powodu w całej Unii Europejskiej. Z danych unijnego urzędu statystycznego wynika również, że w Polsce wydano 635 tys. tak zwanych pierwszych pozwoleń na pobyt - są one udzielane osobom, które przyjeżdżają do danego kraju pierwszy raz. Polska jest liderem pod tym względem.

W 2018 r. aż 5200 imigrantów otrzymało polskie obywatelstwo. To największa liczba od 2012 r., kiedy doszło do zmian przepisów w tym zakresie. Dawniej nadawanie obywatelstwa było prerogatywą prezydenta, a obecnie można zostać uznanym obywatelem, jeśli spełni się odpowiednie kryteria i złoży wniosek, tak jak w innych krajach Unii Europejskiej. Aby otrzymać obywatelstwo polskie, trzeba mieszkać w Polsce na podstawie zezwolenia na pobyt stały przez co najmniej trzy lata. Wcześniej powinno się mieć pobyt czasowy, więc cały proces trwa od siedmiu do ośmiu lat. Pozostałe warunki to posiadanie w Polsce stałego i stabilnego źródła dochodu oraz prawa do lokalu (wystarczy umowa najmu). Trzeba też udokumentować znajomość języka polskiego na poziomie minimum B1. Wniosek składa się w urzędzie wojewódzkim. Skrócony czas starań o polskie obywatelstwo przysługuje osobom ze statusem uchodźcy oraz repatriantom - muszą oni mieszkać w Polsce od co najmniej dwóch lat. Podobny czas dotyczy tych cudzoziemców, którzy od co najmniej trzech lat pozostają w związku małżeńskim z Polakiem lub Polką (Personnel Service, 2018).

W 2020 r. w związku z pandemią wprowadzono zmiany w prawie, przewidujące m.in. szczególne rozwiązania dla cudzoziemców w Polsce. Umożliwiają one legalne pozostawanie w kraju osobom, które „chca realizować dotychczasowy cel pobytu lub nie mogą opuścić Polski w związku z rozprzestrzenianiem się wirusa SARS-CoV-2" (Urząd ds. Cudzoziemców, 2020).

W 2020 r. liczba cudzoziemców posiadających ważne zezwolenia na pobyt w Polsce przekroczyła 450 tys. osób. W pierwszej połowie 2020 r. grupa ta zwiększyła się o prawie 27 tys. osób. Przeważali obywatele Ukrainy, głównie były to osoby młode, poniżej 35 roku życia. Najwięcej cudzoziemców, prawie 267 tys. osób, posiadało zezwolenia na pobyt czasowy, które mogą być wydane na maksymalnie trzy lata. Natomiast grupa obcokrajowców uprawnionych do pobytu stałego oraz posiadających status rezydenta długoterminowego liczyła 95,8 tys. osób. Zarejestrowany pobyt miało także prawie 82 tys. obywateli państw członkowskich Unii Europejskiej (Urząd ds. Cudzoziemców, 2020).

W pierwszej połowie 2020 r. największy wzrost liczby obcokrajowców osiedlających się w Polsce dotyczył obywateli:Ukrainy-o 21,8 tys. osób; Białorusi-o 2,4tys. osób; Gruzji - o 1,5 tys. osób; Mołdawii - o 0,7 tys. osób oraz Turcji - o 0,3 tys. osób (Urząd ds. Cudzoziemców, 2020).

\section{IMIGRANCI W PABIANICACH}

\subsection{RUCHY MIGRACYJNE OD XIX W. DO I WOJNY ŚWIATOWEJ}

Po Kongresie Wiedeńskim w 1815 r. Pabianice weszły w skład Królestwa Polskiego. Władze Królestwa w 1920 r. wydały dekret, dotyczący wytypowania osad, które miały stać się ośrodkami przemysłu włókienniczego. Wybrana została Łódź, jak i okoliczne miasta. W wyniku zaleceń dekretu rozpoczęto regulację Pabianic, w tym budowę przemysłowej dzielnicy na zachód od rzeki Dobrzynki. Do Pabianic zaczęli przybywać cudzoziemscy sukiennicy, głównie ze Śląska, z Saksonii i Czech. Zgodnie z prawem Królestwa Polskiego potencjalni osadnicy mieli zapewnione: działki budowlane, grunty pod uprawy poza miastem, zwolnienia z wielu opłat, możliwość skorzystania z pożyczek państwowych na rozbudowę przedsiębiorstw oraz usprawnioną politykę celną dotyczącą sprzedaży towaru w granicach Imperium Rosyjskiego (Missalowa, 1968).

W latach 20. i 30. XIX w. osadnicy niemieccy uruchomili pierwsze farbiarnie i drukarnie tkanin, współpracując z chałupnikami tkackimi najczęściej żydowskiego 
Tabela 2. Ludność Pabianic według narodowości w 1865 i 1913 r.

\begin{tabular}{|c|c|c|c|c|c|c|c|c|c|}
\hline \multirow{3}{*}{ Rok } & \multicolumn{8}{|c|}{ Narodowość } & \multirow{3}{*}{$\begin{array}{c}\text { Ogółem } \\
\text { liczba osób } \\
\end{array}$} \\
\hline & \multicolumn{2}{|c|}{ Polacy } & \multicolumn{2}{|c|}{ Niemcy } & \multicolumn{2}{|c|}{ Żydzi } & \multicolumn{2}{|c|}{ Rosjanie } & \\
\hline & liczba osób & udział \% & liczba osób & udział \% & liczba osób & udział \% & liczba osób & udział \% & \\
\hline 1865 & 3422 & 57,7 & 1634 & 23,9 & 1088 & 18,4 & - & - & 6144 \\
\hline 1913 & 32696 & 67,5 & 5918 & 12,2 & 9558 & 19,8 & 242 & 0,5 & 48414 \\
\hline
\end{tabular}

Źródło: Krzykowski (2019).

pochodzenia. Dzięki tym dwóm grupom narodowościowym powstawały prywatne manufaktury, a w II połowie XIX w. fabryki - między innymi braci Baruch, O. Kindlera, S. Arkusza, K. Lewickiego., L. Schweikerta, W. Kruschego czy E. Saengera (Missalowa, 1968; Warneńska, 1963). W 1874 r. pabianicka fabryka niemieckich wspólników „Krusche \& Ender” stała się jednym z największych producentów wyrobów bawełnianych w Królestwie Polskim. Skupiała 83\% produkcji włókienniczej miasta (Puś, 1992).

Polacy stanowili ponad połowę ludności Pabianic. W XIX w. drugą najliczniejszą grupą narodowościową byli Niemcy, a trzecią Żydzi. Na początku XX w. udział Żydów się zwiększył, natomiast Niemców zmniejszył. Rosjanie, przedstawiciele władz, stanowili zaledwie 0,5\% mniejszość narodową (tab. 2).

Intensywny rozwój gospodarczy miasta spowodował wzrost liczby ludności, która w ciągu 50 lat powiększyła się ponad sześciokrotnie z 3,9 tys. osób w $1846 \mathrm{r}$. do 25,4 tys. w 1896 r. (Baruch, 1903). W latach 1865-1913 wzrost ten był jeszcze większy, bo przeszło dziewięcioipółkrotny (tab. 2).

Cudzoziemcy przyczynili się do wzrostu gospodarczego Pabianic, przede wszystkim do rozwoju przemysłu włókienniczego. Dzięki obcokrajowcom powstały w przestrzeni miasta nie tylko fabryki, lecz także świątynie (ewangelicka, baptystów, rzymskokatolicka, synagoga), szkoły, szpitale, wille i pałace fabrykantów, osiedla domów robotniczych oraz straż pożarna. Budowle te w części zachowały się do czasów współczesnych (Barwiński, 2016; Rykała, 2013).

W pierwszej połowie XIX w. relacje między Polakami a cudzoziemskimi osadnikami były bardzo dobre. Utworzenie nowych miejsc pracy umożliwiło podniesienie poziomu życia, a poprawa sytuacji ekonomicznej miasta, głównie z inicjatywy Niemców i Żydów, sprawiła, że Polacy byli pozytywnie nastawieni do nowych mieszkańców (Missalowa, 1968).

Imigranci dziewiętnastowieczni najczęściej osiedlali się w Pabianicach na stałe, a ich potomkowie czuli się pabianiczanami. Stali się przedstawicielami mniejszości narodowych w mieście. Wielu pabianiczan obecnie żyjących w mieście posiada, często spolszczone, nazwiska - niemieckie np. Hildebrandt, Hajnce, Fątner, Flajszer, Friedenberger, żydowskie np. Baruch, Lewicki, rosyjskie np. Pobielajew, Seliwiorstow, czy czeskie np. Stanek, Morawiec. Jest to skutek zawierania przez polskich mieszkańców związków małżeńskich z cudzoziemcami (Krzykowski, 2019).

\subsection{ZAHAMOWANIE RUCHÓW MIGRACYJNYCH W XX W.}

Po I wojnie światowej Pabianice zamieszkiwali przedstawiciele 11 narodowości, z czego Polacy, Żydzi i Niemcy nadal stanowili większość (tab. 3). Udział Polaków w 1921 i 1931 r. przekraczał 72\%, zwiększała się liczba Niemców, a zmniejszała Żydów, którzy wciąż stanowili najliczniejsza, po Polakach, grupę narodowościową. W 1921 r. w mieście mieszkało zaledwie dziewięciu Rosjan, a 10 lat później nie było już żadnego przedstawiciela tej mniejszości narodowej (tab. 3). Tę strukturę narodowościową całkowicie zburzyła II wojna światowa.

Po wojnie w Pabianicach można było odnaleźć tylko niewielkie grupy Żydów i Niemców. W 1946 r. w pabianickim komitecie żydowskim zarejestrowanych było ok. 100 osób, natomiast w 1947 roku ok. 130 osób (Rykała, 2013). Populacja Niemców w owym czasie liczyła ok. 1000 osób (Kruś, 2016). W 1950 r. i 1960 r. narodowości te znikały z miasta $\mathrm{w}$ wyniku dobrowolnej

Tabela 3. Ludność Pabianic według narodowości w 1921 i 1931 r.

\begin{tabular}{|c|c|c|c|c|c|c|c|c|c|}
\hline \multirow{3}{*}{ Rok } & \multicolumn{8}{|c|}{ Narodowość } & \multirow{3}{*}{$\begin{array}{c}\text { Ogółem } \\
\text { liczba osób }\end{array}$} \\
\hline & \multicolumn{2}{|c|}{ Polacy } & \multicolumn{2}{|c|}{ Niemcy } & \multicolumn{2}{|c|}{ Żydzi } & \multicolumn{2}{|c|}{ Rosjanie } & \\
\hline & liczba osób & udział \% & liczba osób & udział \% & liczba osób & udział \% & liczba osób & udział \% & \\
\hline 1921 & 21469 & 72,4 & 1634 & 5,5 & 6539 & 22,07 & 9 & 0,03 & 29651 \\
\hline 1931 & 33005 & 72,3 & 4494 & 9,8 & 8117 & 17,8 & - & - & 45616 \\
\hline
\end{tabular}

Źródło: Krzykowski (2019). 
emigracji lub przymusowego wysiedlenia. Polityka narodowościowa Polskiej Rzeczpospolitej Ludowej dyskryminowała mniejszości narodowe. W latach 19501989 w Pabianicach mieszkała bardzo mała grupa cudzoziemców - 5 osób w 1950 r. i 25 osób w 1985 r. (Urząd Miasta w Pabianicach).

Grupą o obcym pochodzeniu, już nie narodowym a etnicznym, która przybyła w tamtym czasie do Pabianic, byli Romowie. Pierwsi przedstawiciele tej mniejszości pojawili się w mieście na przełomie lat 70. i 80. $X X$ w. Populacja romska w następnych latach szybko rosła, gdyż zaczęli sprowadzać się kolejni członkowie rodzin (Kowarska, 2005). Ich dokładna liczba nie jest znana, gdyż w tamtym czasie nie było możliwości zatwierdzenia romskiego pochodzenia $w$ wydziałach ewidencji ludności. Romów uznawano za Polaków, co było przykładem asymilacyjnej polityki narodowościowej ówczesnej Polski. Reprezentowali oni najliczniej występującą w Polsce grupę klanowo-plemienną, czyli tak zwaną Polską Romę (Szyszlak, 2011).

\subsection{INTENSYWNA IMIGRACJA NA POCZĄTKU XXI W.}

Współczesne Pabianice, położone w bezpośrednim sąsiedztwie Łodzi, są trzecim miastem pod względem liczby ludności w województwie łódzkim, po Łodzi i Piotrkowie Trybunalskim, o zaludnieniu rzędu 65 tys. osób. Liczba ludności miasta sukcesywnie maleje, o ok. 500 osób rocznie (rys. 3).

Wejście Polski do UE (2004 r.) i strefy Schengen (2007 r.) oraz wprowadzenie możliwości zatrudniania imigrantów na podstawie oświadczenia pracodawcy składanego w powiatowym urzędzie pracy (od 2007 r.) spowodowało napływ obcokrajowców do naszego kraju. W kolejnych latach odnotowano znaczny wzrost liczby imigrantów, największy w 2015 r. Przyjeżdżali głównie Ukraińcy, co było spowodowane gwałtownym pogorszeniem się sytuacji politycznej i gospodarczej na Ukrainie na przełomie 2013 i 2014 r.

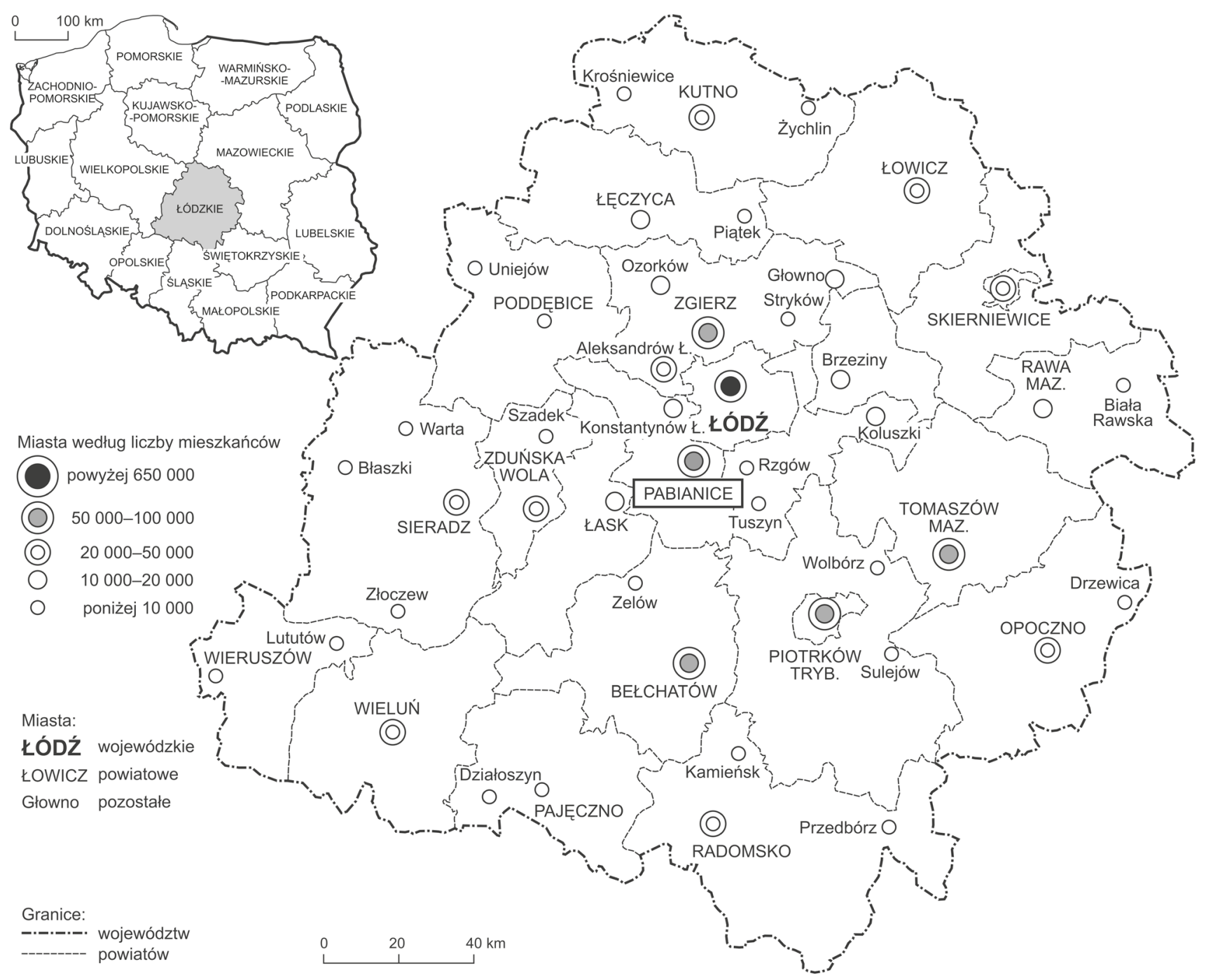

Rysunek 3. Położenie Pabianic w województwie łódzkim Źródło: opracowanie własne 
W samych Pabianicach liczba cudzoziemców wzrosła przeszło 10-krotnie - od 27 osób w 1990 r. do 290 osób w 2018 r. Wśród osób tych przeważali mężczyźni. Trzeba jednak podkreślić, iż oficjalne statystyki nie odzwierciedlają prawdziwej liczby cudzoziemców, gdyż część z nich pracuje w szarej strefie (rys. 4) (Krzykowski, 2019).
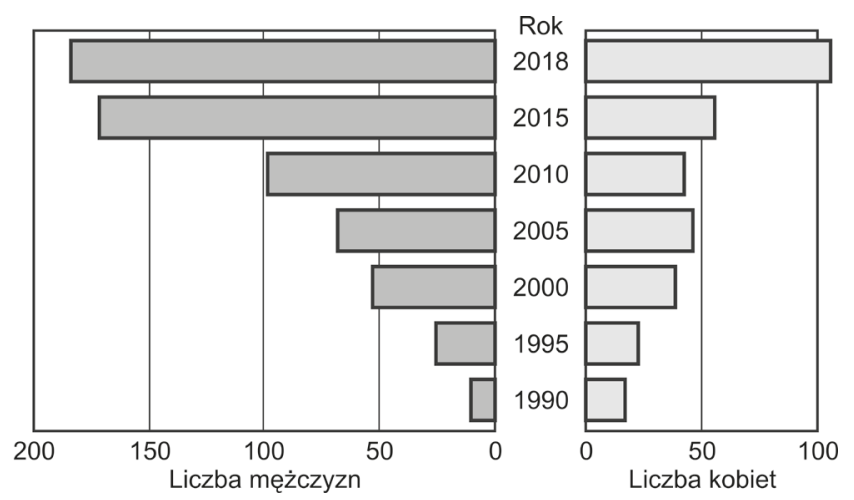

Rysunek 4. Liczba cudzoziemców w Pabianicach w latach 1990-2018

Źródło: opracowanie własne na podstawie danych pozyskanych z Urzędu Miasta w Pabianicach

W latach1990-2018 w Pabianicach pojawiło się 68 przedstawicieli różnych narodów. Pochodzili oni głównie z byłych republik ZSRR - Ukrainy, Białorusi i Armenii, krajów Azji Południowej - z Indii i Pakistanu oraz z państw Europy Zachodniej - Holandii, Belgii, Włoch, Niemiec (rys. 5). Mniejsza grupa obcokrajowców, przeważnie pojedyncze osoby, przyjechała z: Afryki - z Algierii, Nigerii, Republiki Południowej Afryki; Ameryki
Południowej-z Brazylii, Ameryki Północnej-ze Stanów Zjednoczonych (Krzykowski, 2019).

Najliczniej reprezentowani byli obywatele Ukrainy i Indii, których udział w ogólnej liczbie imigrantów w 2018 r. przekraczał w sumie 71\% (rys. 6).

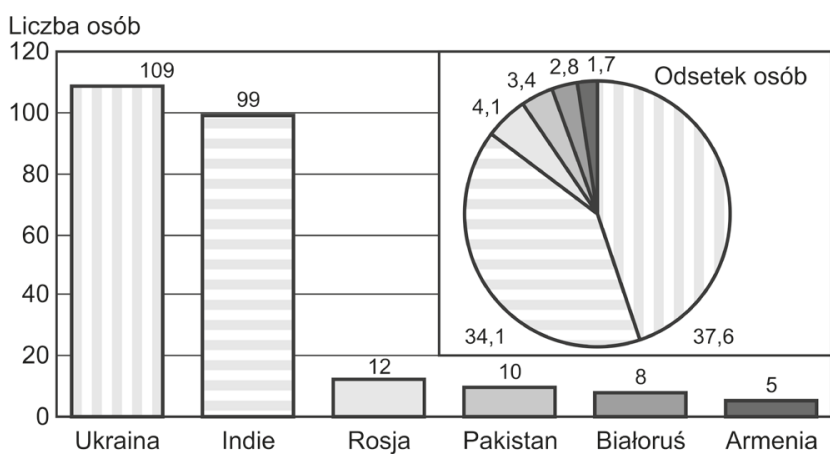

Rysunek 6. Kraje pochodzenia

najliczniejszych grup imigrantów w Pabianicach w 2018 r. Źródło: opracowanie własne na podstawie danych pozyskanych z Urzędu Miasta w Pabianicach

Aby scharakteryzować imigrantów funkcjonujących w Pabianicach, przeprowadzono w 2018 i 2019 r. badania ankietowe zarówno wśród cudzoziemców, jak i mieszkańców. W pierwszej grupie respondentów, w doborze 70-osobowej próby użyto metody celowej, docierając z ankietą do miejsc, w których pracowali cudzoziemcy (były to: sklepy z zagranicznymi produktami, restauracje serwujące hinduskie, chińskie i tureckie potrawy, supermarkety i zakłady przemysłowe na terenie Pabianic oraz hurtownie tkanin zlokalizowane wzdłuż drogi krajowej nr 71 na odcinku Pabianice-

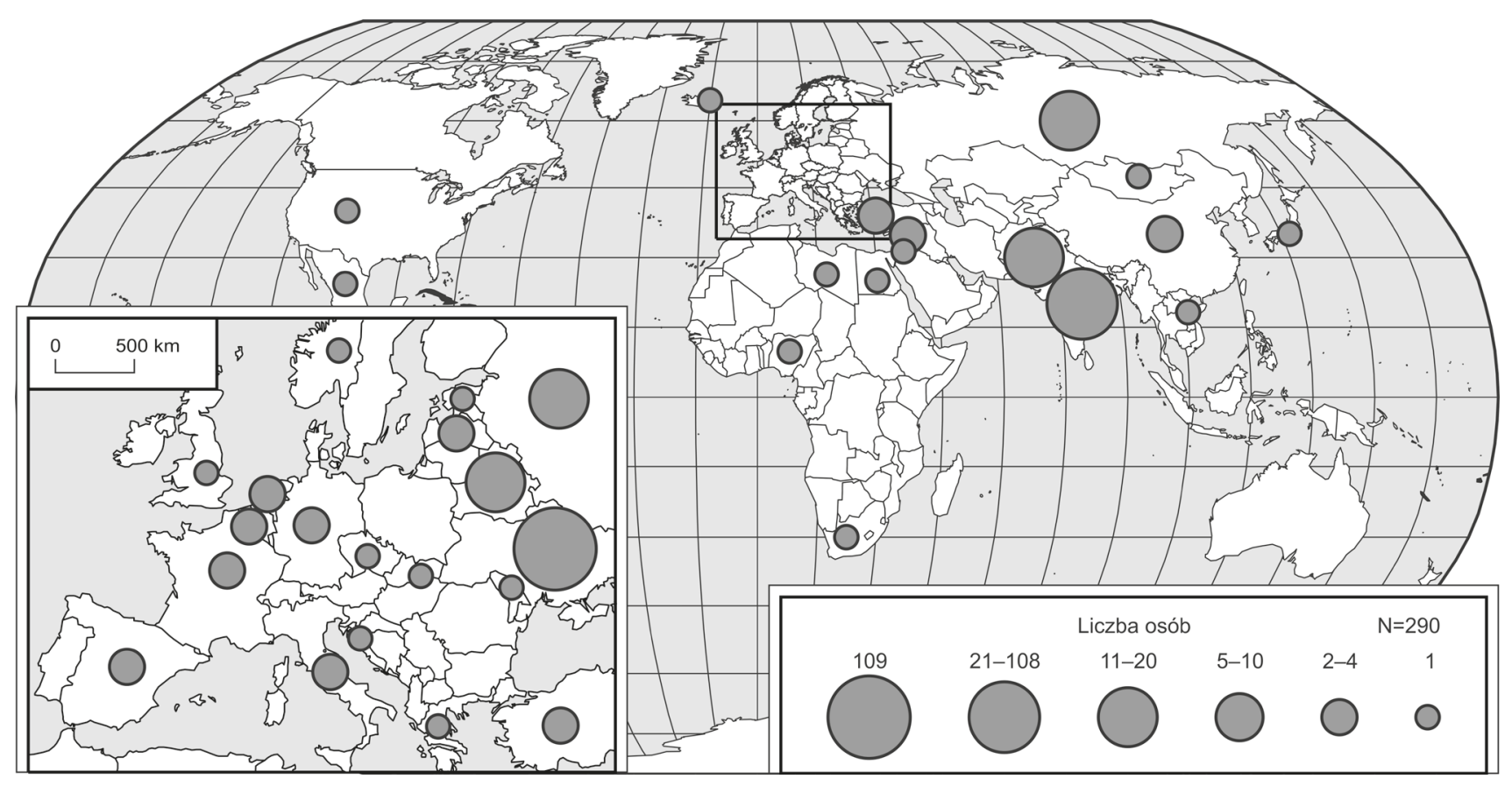

Rysunek 5. Pochodzenie cudzoziemców przybywających do Pabianic w latach 1990-2018 Źródło: opracowanie własne na podstawie danych pozyskanych z Urzędu Miasta w Pabianicach 
Rzgów). Ankieta skierowana do cudzoziemców napisana była w językach: polskim, ukraińskim i angielskim (Krzykowski, 2019).

Badanie przeprowadzono również wśród 250 mieszkańców Pabianic, aby dowiedzieć się, jak postrzegają działalność cudzoziemców, którzy pracowali w mieście w przeszłości i współcześnie. Zdecydowana większość respondentów (76\%) mieszkała w Pabianicach od urodzenia. Prezentowali oni przede wszystkim dwie grupy wiekowe - powyżej 60 roku życia (26\%) oraz ok. 20-30 roku życia $(23,6 \%)$, deklarowali wykształcenie średnie i wyższe $(76,4 \%)$, a pracowali w usługach (71,3\%) oraz w przemyśle (26,3\%). Swój stosunek do polityki migracyjnej UE 2/3 badanych określiło jako bardzo dobry, dobry i średni.

Mieszkańcy posiadali podstawowe informacje o pabianickich cudzoziemcach, żyjących kiedyś i obecnie w mieście, o krajach ich pochodzenia, wyznaniach, wpływie na rozwój miasta. Ankietowani wymienili 32 różne obiekty i miejsca, związane z działalnością cudzoziemców w XIX w. i okresie międzywojennym. Najczęściej wskazywano największą fabrykę włókienniczą dawnej spółki „Krusche \& Ender”, oraz inne fabryki (M. Barucha, R. Kindlera), pałace fabrykantów (T. Endera, R. Kindlera, B. Kruschego), kościoły (ewangelicki pw. św. Mateusza i katolicki pw. Najświętszej Maryi Panny) oraz cmentarze - ewangelicki i żydowski (Krzykowski, 2019).

Ponad połowa badanych mieszkańców (52\%) wskazała, iż Pabianice współcześnie także są miastem wielokulturowym. Większość ankietowanych (71\%) dostrzegała ślady działalności cudzoziemców w Pabianicach - restauracje (hinduskie i chińskie) i bary (tureckie), hinduskie hurtownie tkanin, sklepy z chińskimi i hinduskimi towarami, romskie domy o specyficznej ozdobnej architekturze. Najczęściej wymieniano w ankiecie cudzoziemców o narodowości ukraińskiej i hinduskiej. Niektórzy respondenci znali obcokrajowców osobiście jako współpracowników z zakładów przemysłowych. Pabianiczanie widzieli ich pozytywny, ale znacznie słabszy niż w XIX w. wpływ na życie gospodarcze miasta. Jedynie o romskiej mniejszości etnicznej mieli negatywna, często stereotypowa, opinię - wskazywano na działalność przestępczą Romów (Krzykowski, 2019).

W przebadanej grupie 70 cudzoziemców mieszkających i pracujących w Pabianicach większość stanowiły osoby młode, w wieku od 20 do 40 lat (63\%), deklarujące średnie i wyższe wykształcenie (53\%) (rys. 7)

Najliczniejszą grupę narodową tworzyli Ukraińcy (37\%), którzy przybyli głównie z zachodniej Ukrainy (okolice Lwowa i Zakarpacia). Podobnie liczną grupę stanowili Hindusi (34\%), którzy w ostatniej dekadzie zaczęli przyjeżdżać do Pabianic. Pochodzili oni głównie z części północno-zachodniej Indii, znanej z wytwarzania tkanin i handlu nimi, a konkretnie z miast, które

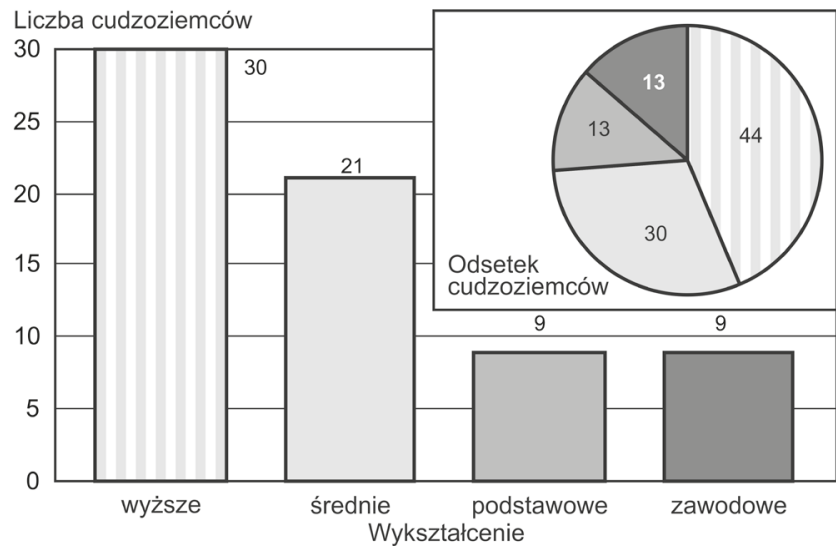

Rysunek 7. Struktura wykształcenia respondentów-cudzoziemców

Źródło: opracowanie własne na podstawie Krzykowski (2019)

posiadają tradycje włókiennicze - Czandigarh, Jodhpur, Ajmer i Konya.

Respondenci byli zróżnicowani pod względem wyznania, katolicyzm deklarowały osoby pochodzące z zachodniej Ukrainy, a przynależność do prawosławia pozostali Ukraińcy, Rosjanin oraz Białorusin. Hindusi przyznawali, że są wyznawcami hinduizmu, a pochodzący z Bangladeszu i Pakistanu to muzułmanie. Buddyzm reprezentował ankietowany Chińczyk (rys. 8.) (Krzykowski, 2019).

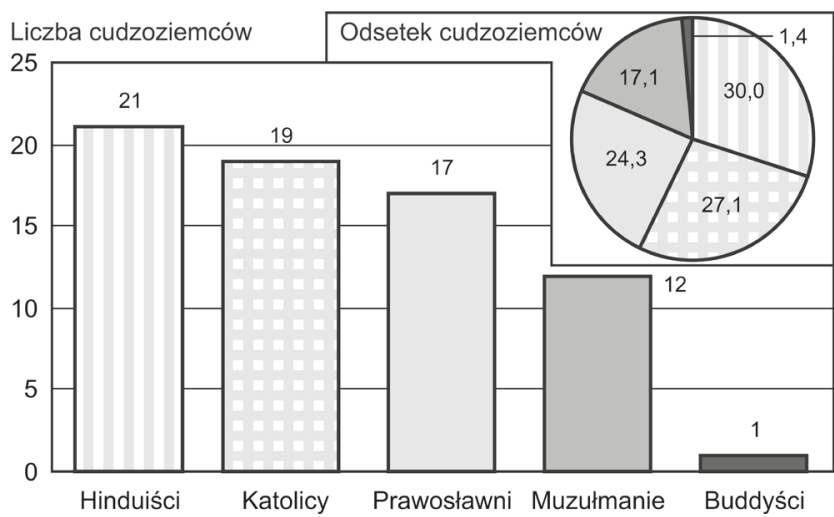

Rysunek 8. Struktura respondentów-cudzoziemców według wyznania

Źródło: opracowanie własne na podstawie Krzykowski (2019)

Ankietowani pracowali głównie w usługach. Przeważnie byli to właściciele hurtowni tkanin (31\%), sprzedawcy w hinduskich i chińskich sklepach (15\%), a także pracownicy zakładów przemysłowych (13\%), kucharze (11\%), robotnicy magazynowi (7\%), kasjerki w supermarketach (3\%) oraz pracujaccy na budowach (najczęściej w szarej strefie). Romowie deklarowali prowadzenie działalności gospodarczej (13\%) (rys. 9) (Krzykowski, 2019).

Z ankiety wynika, że duża część imigrantów nie zamierzała zostać w Pabianicach na stałe. Ukraińcy mieszkali najczęściej krócej niż rok - zwykle pracują 


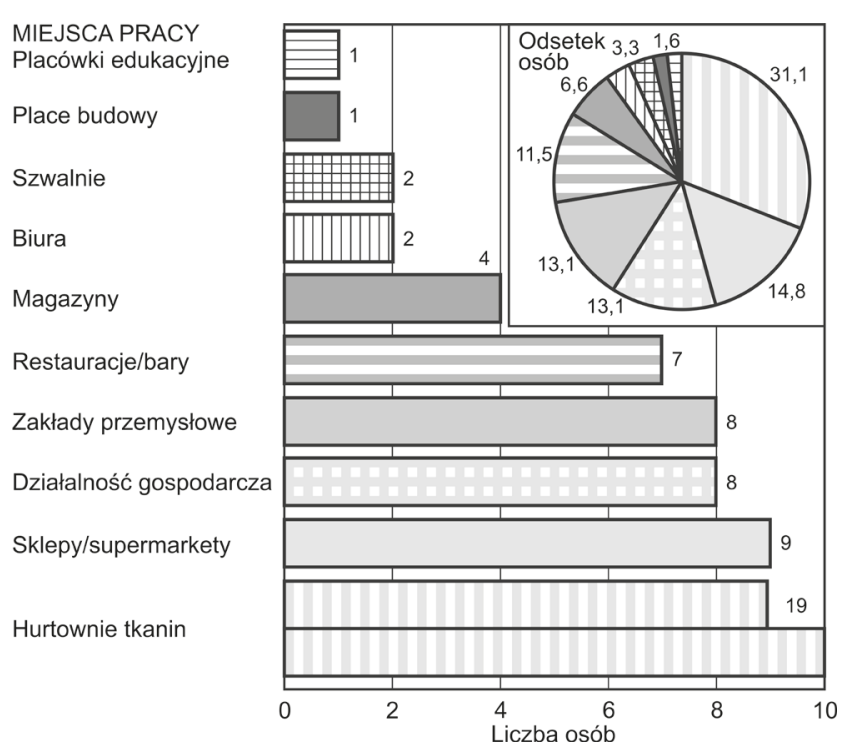

Rysunek 9. Miejsca pracy badanych cudzoziemców Źródło: opracowanie własne na podstawie Krzykowski (2019)

oni w okresie letnim i wracają do domów na zimę. Ponad 10 lat przebywały w mieście osoby, które zawarły związek małżeński z Polakiem/Polką i założyły tutaj rodzinę. Najwięcej badanych osób mieszkało z żona/ mężem, którzy najczęściej byli tej samej narodowości (31\% ), oraz z dziećmi (21\%).

Większość Hindusów wynajmowała lub kupowała domy, często od Romów. Ukraińcy i Białorusini najczęściej wynajmowali, rzadko kupowali mieszkanie w bloku lub kamienicy. Z kolei obcokrajowcy z Bliskiego i Dalekiego Wschodu (np. Syryjczycy, Chińczycy) wynajmowali mieszkanie lub tylko pokój w bloku bądź kamienicy. Zdecydowana większość respondentów (82\% ogółu) oceniła warunki swojego mieszkania jako dobre lub bardzo dobre (Krzykowski, 1969).

Większość obcokrajowców biorących udział w badaniu $(82 \%)$ deklarowała, że Polacy wykazują dobry lub średni stosunek do ich narodowości. Kilka osób, w tym Ormianie i Hindusi, określiło stosunek pabianiczan polskiego pochodzenia do ich narodowości jako bardzo dobry. Z kolei Romowie odczuwali dużą niechęć i wrogość wobec swojej kultury.

\section{PODSUMOWANIE}

Pabianice, podobnie jak inne miasta Królestwa Polskiego, wytypowane do rozwoju przemysłu włókienniczego w XIX w.zaludniali, oprócz Polaków, cudzoziemcy-przede wszystkim Niemcy i Żydzi. Pozostawili po sobie bogatą spuściznę - liczne, zabytkowe już obiekty, począwszy od fabryk - głównie włókienniczych, przez pałace i wille, po kościoły, cmentarze, szkoły, szpitale. Druga wojna światowa i okres PRL-u spowodowały, że wszystkie mniejszości narodowe zniknęły z przestrzeni miasta. Jedyną mniejszością etniczną, która stale pozostawała w Pabianicach od 1970 r., byli Romowie.

Drugim okresem intensywnej imigracji do Pabianic stał się początek XXI w. Po wejściu Polski do UE zaczęli napływać do naszego kraju imigranci, przede wszystkim spoza UE. Była to typowa migracja ekonomiczna. W 2019 r. w Polsce wydano najwięcej zezwoleń na pracę $\mathrm{w}$ porównaniu do całej UE.

Ukraińcy i Hindusi to dwie najliczniejsze grupy zamieszkujące Pabianice, które stanowią dziś ponad 71\% ogółu mniejszości narodowych pracujących w mieście. Hindusi założyli hurtownie tkanin oraz restauracje, kupili domy lub mieszkania i osiedlili się w mieście. Inne nacje również pracują głównie w usługach, ale także na placach budowy i w zakładach przemysłowych. Poza Hindusami i nielicznymi przedstawicielami cudzoziemców z UE, pozostali przyjeżdżają do miasta $\mathrm{w}$ celach zarobkowych i po półrocznym pobycie wracają do swojego kraju, by po jakimś czasie znowu przyjechać do pracy. Na ogół nie zamierzają oni osiedlać się w naszym kraju na stałe.

Badani pabianiczanie wykazali podstawową wiedzę o cudzoziemcach żyjących dawniej i obecnie w mieście, o krajach ich pochodzenia, wyznaniach, wpływie na rozwój miasta. Potrafili wskazać dziewiętnastowieczną spuściznę, która pozostała po dawnych nacjach. O współczesnych imigrantach wypowiadali się na ogół pozytywnie.

\section{PRZYPISY}

${ }^{1}$ PwC - globalna sieć przedsiębiorstw świadczących usługi księgowe, audytorskie i doradcze, utworzona w 1998 r. w wyniku połączenia Price Waterhouse oraz Coopers \& Lybrand.

${ }^{2}$ Personnel Service - firma zajmująca się rekrutacją i zatrudnianiem pracowników z Ukrainy w Polsce.

\section{BIBLIOGRAFIA}

Adamek, R., Nowak, T. (2005). 650 lat Pabianic: studia i szkice. Łódź: Wydawnictwo Literatura.

Baruch, M. (1903). Pabianice, Rzgów i wsie okoliczne. Monografia historyczna dawnych dóbr kapituły krakowskiej w sieradzkiem i łęczyckiem. Warszawa: Skład Główny w Księgarni E. Wende i S-ka.

Barwiński, M. (2016). Mniejszości narodowe i etniczne w polskiej przestrzeni publicznej. W: A. Rykała (red.), Mniejszości narodowe i etniczne w interpretacjach przestrzennych. Studia z Geografii Politycznej i Historycznej. T. 5 (s. 93-94). Łódź: Wydawnictwo Uniwersytetu Łódzkiego.

Brunarska, Z., Gotte, M., Lesińska, M. (2012). Migracje obywateli Ukrainy do Polski w kontekście rozwoju społeczno-gospodarczego: stan obecny, polityka, transfery pieniężne. CMR Working Papers, 60 (118), 1-90.

Chmielewska, J., Dobraczek, G., Purynkiewicz, J. (2016). Obywatele Ukrainy pracujacy w Polsce - raport z badania. Warszawa: Departament Statystyki NBP. 
Eurostat (2020). Pobrane z: https://ec.europa.eu/ (11.10.2020).

Gmaj, K. (2015). Dlaczego Polska? W: I. Bąbiak, K. Gmaj (red.), Namaste Polsko! Sytuacja i potrzeby imigrantów z Indii w Polsce (s. 24-26). Warszawa: Wydawnictwo Scholar.

Górny, A., Grabowska-Lusińska, I., Lesińska, M., Okólski, M. (red.) (2010). Transformacja nieoczywista. Polska jako kraj imigracji. Warszawa: Wydawnictwa Uniwersytetu Warszawskiego.

Górny, A., Kołodziejczyk, K., Madej, K., Kaczmarczyk, P. (2019). Nowe obszary docelowe w migracji z Ukrainy do Polski. Przypadek Bydgoszczy i Wroctawia na tle innych miast. Warszaw: Ośrodek Badań nad Migracjami.

Jakóbczyk-Gryszkiewicz, J. (2016). Imigranci spoza UE w Polsce, Łodzi i regionie łódzkim. Acta Universitatis Lodziensis. Folia Geographica Socio-Oeconomica, Studia regionalne, 26, 146-151. https://doi.org/10.18778/1508-1117.26.08

Jakóbczyk-Gryszkiewicz, J. (2018). Czy imigracja jest szansą dla wyludniających się polskich miast? Wybrane rodzaje ruchów migracyjnych, Przeglad Geograficzny, 2, 291-308. https://doi. org/10.7163/PrzG.2018.2.5

Klimek, A. (2012). Aktywność społeczna oraz relikty dziedzictwa materialnego ewangelików augsburskich w Pabianicach. W: A. Rykała (red.), Studia z Geografii Politycznej i Historycznej. Granice, mniejszości narodowe, dziedzictwo. T. 1 (s. 196-197). Łódź: Wydawnictwo Uniwersytetu Łódzkiego.

Klimek, D. (2015). Funkcja ekonomiczna migracji zarobkowej z Ukrainy do Polski. Łódź: Wydawnictwo Politechniki Łódzkiej.

Kloc-Nowak, W. (2007). Funkcjonowanie imigrantek z Ukrainy na polskim rynku pracy - sytuacja obecna i rekomendacje dla społeczeństwa przyjmujacego. Warszawa: Stowarzyszenie Interwencji Prawnych.

Konieczna-Sałamatin, J. (2015). Imigracja do Polski w świetle danych urzędowych. Warszawa: Centrum Obsługi Projektów Europejskich Ministerstwa Spraw Wewnętrznych.

Kowarska, A.J. (2005). Polska Roma: tradycja i nowoczesność. Warszawa: Wydawnictwo DiG.

Kruś, A. (2016). Społeczno-religijna rola luteranów w dziejach Pabianic i Zgierza oraz relikty ich dziedzictwa materialnego. Acta Universitatis Lodziensis. Folia Geographica Socio-Oeconomica. Geografia Historyczna. Wybrane współczesne problemy badawcze, 25, 159-163. https://doi.org/10.18778/1508-1117.25.08

Krzykowski, D. (2019). Cudzoziemcy w Pabianicach. Wielokulturowośc miasta - prawda czy fatsz?, praca magisterska napisana pod kierunkiem prof. dr hab. J. Jakóbczyk-Gryszkiewicz, Instytut Geografii Miast, Turyzmu i Geoinformacji, Wydział Nauk Geograficznych, Uniwersytet Łódzki.

Lesińska, M., Okólski, M. (red.) (2013). Wspótczesne polskie migracje: strategie - skutki społeczne - reakcja państwa. Warszawa: Wydawnictwo Uniwersytetu Warszawskiego. https://doi. org/10.31338/uw.9788323519300
Lubicz-Miszewski, M. (red.) (2018). Imigranci z Ukrainy w Polsce. Potrzeby i oczekiwania, relacje społeczne, wyzwania dla bezpieczeństwa. Warszawa: Wydawnictwo Akademii Wojsk Lądowych.

Marszał, T. (2020). Mniejszość niemiecka w Polsce Środkowej. Geneza, rozmieszczenie i struktura od końca XVIII w. do II wojny światowej. Łódź: Wydawnictwo Uniwersytetu Łódzkiego.

Missalowa, G. (red.) (1968). Dzieje Pabianic. Łódź: Wydawnictwo Łódzkie.

ONS (2020). Pobrane z: https://www.ons.gov.uk/ (11.10.2020).

Paszkowicz, M.A., Hrynenko, A. (2019). Przyczyny i skutki migracji zarobkowych z Ukrainy do Polski. Studia Oeconomica Posnaniensia, 7 (4), 7-26. https://doi.org/10.18559/SOEP.2019.4.1

Patzer, H. (2015). Diaspora hinduska w Polsce. Utrzymywanie więzi transnarodowych, tworzenie stowarzyszeń. W: I. Bąbiak, K. Gmaj (red.), Namaste Polsko! Sytuacja i potrzeby imigrantów $z$ Indii w Polsce (s. 60-62). Warszawa: Wydawnictwo Scholar.

Pędziwiatr, K. (2015). Imigracja w Polsce i wyzwania integracyjne, Infos BAS, 1 (184), 1-4.

Personnel Service (2018). Barometr Imigracji Zarobkowej w I pótroczu 2018 r. Pobrane z: https://personnelservice.pl/wp-content/ uploads/2020/07/BarometrImigracjiZarobkowej_raport.pdf (15.09.2020).

Puś, W. (1992). Przemysł Pabianic w latach 1865-1914. Pabianiciana. $1,75-84$.

PwC (2019). Rosnaca luka na rynku pracy w Polsce. Jak ją zniwelować? Pobrane z: https://www.slideshare.net/PwCPolska/rosnca-luka-na-rynku-pracy-w-polsce (15.10.2020).

Rykała, A. (2013). Działalność społeczno-kulturalna mniejszości narodowych i religijnych w przestrzeni miejskiej Pabianic do drugiej wojny światowej. Studia z Geografii Politycznej $i$ Historycznej. Przestrzenny wymiar wielokulturowego dziedzictwa, 2, 263-302.

Szyszlak, T. (2011). Kwestia romska w polityce państw Europy Środkowej $i$ Wschodniej, Wrocław: Fundacja Integracji Społecznej Prom.

Urząd ds. Cudzoziemców (2020). Epidemia koronawirusa - specjalne rozwiazania dla cudzoziemców. Pobrane z: https://udsc. gov.pl/epidemia-koronawirusa-specjalne-rozwiazania-dla-cudzoziemcow/ (1.10.2020).

Urząd ds. Cudzoziemców (2020). Pobrane z: https://udsc.gov. $\mathrm{pl} /(1.10 .2020)$.

Warneńska, M. (1963). Fortuna rodu Krusche. Łódź: Wydawnictwo Łódzkie.

Artykuł wpłyną:

3 listopada 2020

Zaakceptowano do druku:

17 grudnia 2020 